\title{
Phenolic compounds as the major antioxidants in red cabbage
}

\author{
Maria Leja, Iwona Kamińska, Anna Kołton
}

\author{
Department of Plant Physiology \\ Faculty of Horticulture, Agricultural University \\ 29 Listopada 54, 31-425 Kraków, Poland \\ email:m.leja@ogr.ur.krakow.pl
}

\begin{abstract}
In the heads of four red cabbage cultivars and two DH lines (one of red and one of white type), as well as in the standard white cabbage 'Lennox $\mathrm{F}_{1}$ ' cultivar, the contents of phenolic substances (total, phenylpropanoids, flavonols and anthocyanins) were estimated. Antiradical scavenging activity was determined using the DPPH and ABTS methods. The level of phenolics of all the groups, especially that of the anthocyanins, as well as RSA, was much higher in red cabbage in comparison to white. Among red cabbage assays, also a considerable variability of antioxidative parameters was observed. Four-month commercial storage resulted in a significant reduction in phenol compounds in red cabbage, but this was not the case in the white cultivar.

Radical scavenging activity did not significantly change after cold storage, except in 2005/06, when a decrease in RSA measured by the DPPH method was noticed. The values of RSA determined by the ABTS method exceeded those determined by DPPH.
\end{abstract}

Key words: antiradical activity, Brassica oleracea var. capitata f. rubra, phenolics

\section{INTRODUCTION}

Brassicaceae vegetables are an abundant source of health-promoting substances, which reduce the risk of diseases. Apart from anticancerogenic glucosinolates, they possess antioxidants of both hydrophilic (vitamin $\mathrm{C}$, polyphenols) and hydrophobic phases (carotenoids, vitamin E), which can neutralize active oxygen species and quench free radicals.

Phenolic compounds with ascorbic acid are major antioxidants of Brassicaceae vegetables, while lipidsoluble antioxidants are responsible for only $20 \%$ of the total antiradical capacity (Podsędek 2007).

Among the analysed Brassica species, Brussels sprouts, broccoli and red cabbage are considered as the vegetables with the most efficient antiradical system (Podsędek 2007). The latter is rich in anthocyanins of high antioxidant activity (Proteggente et al. 2002, Singh et al. 2006, Can and Altiokka 2007).
In our previous investigations with red cabbage of the 'Langedijker' cultivar, grown in field conditions and fertilised with different forms of nitrogen, high levels of phenolic substances as well as high radical scavenging activity were observed (Leja et al. 2005). The high level of vitamin $\mathrm{C}$ did not correspond, however, with the inhibition of lipid peroxidation and activity against hydroxyl radical (Leja et al. 2007).

Because in these studies only one red cabbage cultivar was used, for a better explanation of antioxidative properties of this species, the present experiment is associated with four red cabbage cultivars and two DH lines (one of the white and one of the red type) to compare their antioxidant parameters after harvesting and after long-term commercial storage. Additionally, the 'Lennox $\mathrm{F}_{1}$ ' cultivar was investigated as the standard white cabbage cultivar with beneficial chemical composition and long storage capacity. Phenolic compounds such as 
total phenols, phenylpropanoids (derivatives of cinamic acid), flavonols and anthocyanins were estimated.

\section{MATERIAL AND METHODS}

The experiment was carried out in 2005/06 and in 2006/07. Four red cabbage cultivars ('Langedijker', 'Kissendrup', 'Koda' and 'Haco'), as well as two DH lines (DH 1118-337 of white and DH-509 $\mathrm{R}_{1}$ of red type) and 'Lennox $F_{1}$ ' white cabbage were grown in Kraków in conditions described earlier by Laszczak et al. (2007). The freshly harvested cabbage heads were either analysed immediately or stored for four months in a commercial cold chamber, at $1-2^{\circ} \mathrm{C}$ and at $80-85 \%$ of relative humidity. The mean sample of each replication consisted of five heads. The frozen material was stored at $-20^{\circ} \mathrm{C}$ until analyzed.

For the estimation of phenolic constituents, extracts in $80 \%$ methanol were prepared. Total phenols, phenylpropanoids, flavonols and anthocyanins were determined by the spectrophotometric method given by Fukumoto and Mazza (2000) based on UV/VIS absorption measurements. Chlorogenic acid, caffeic acid and quercetin were used as the standards for total phenols, phenylpropanoids and flavonols, respectively. Anthocyanin content was expressed as a cyanidine, according to its molar extinction.

Radical scavenging activity (RSA) was detected both by methods using DPPH as well as ABTS stable radicals and expressed as the percentage of their neutralisation (Pekkarinen et al. 1999, Cano et al. 2003).
All analyses were made in three replications and the results were statistically verified using Duncan's test for significance at $\mathrm{p}=0.05$.

\section{RESULTS}

\section{Phenolic substances}

The levels of total phenolics in freshly harvested cabbage heads were greatly differentiated and ranged between 31.4-288.3 (2005) and 43.3-248.8 $\mathrm{mg} 100 \mathrm{~g}^{-1} \mathrm{FW}$ (2006). The lowest content of these constituents was observed in the 'Lennox $\mathrm{F}_{1}$ ' white cabbage cultivar and in DH 1118377, the highest in red 'Kissendrup' and 'Langedijker' cultivars, respectively. A considerable variability among red cabbage cultivars was also noticed in both years of the experiment: 209.6-288.3 in 2005 and $116.8-248.8 \mathrm{mg}$ $100 \mathrm{~g}^{-1} \mathrm{FW}$ in 2006 (Tab. 1a).

A similar dependence was found in the case of individual groups of phenolics. The accumulation of phenylpropanoids, flavonols and, particularly, anthocyanins, was very poor in white cabbage cultivars in comparison with the red ones; however, their levels differed significantly among the red cabbage samples (Tabs 1a and 1b). Special attention should be paid to anthocyanins determined in red cabbage, as the content of these compounds ranged between 66.3-105.4 mg 100 $\mathrm{g}^{-1} \mathrm{FW}$ ('Koda' and 'Kissendrup' in 2005) and between 33.5-94.6 mg $100 \mathrm{~g}^{-1} \mathrm{FW}$ ('Koda' and 'Langedijker' in 2006) (Tab. 1b).

Four-month storage caused, in most cases, a significant decrease of phenolic substances in red cabbage heads, while in two examined white cultivars the changes were

Table 1a. Content of individual phenolic groups in the analysed cabbage tissue (mg $\left.100 \mathrm{~g}^{-1} \mathrm{FW}\right)$

\begin{tabular}{|c|c|c|c|c|c|}
\hline \multirow{2}{*}{ Cultivar } & & \multicolumn{2}{|c|}{ Total phenols } & \multicolumn{2}{|c|}{ Phenylpropanoids } \\
\hline & & $2005 / 06$ & $2006 / 07$ & $2005 / 06$ & $2006 / 07$ \\
\hline 'Lenox $F_{1}$ ' & After harvest & $31.4 \mathrm{a}^{*}$ & $47.6 \mathrm{a}$ & $7.4 \mathrm{a}$ & $8.5 \mathrm{a}$ \\
\hline \multirow{2}{*}{$\begin{array}{l}\text { DH 1118-337 } \\
\text { (white type) }\end{array}$} & After harvest & $39.3 \mathrm{a}$ & $43.3 \mathrm{a}$ & $8.9 \mathrm{a}$ & $8.3 \mathrm{a}$ \\
\hline & After storage & $40.0 \mathrm{a}$ & $45.8 \mathrm{a}$ & $7.4 \mathrm{a}$ & $7.0 \mathrm{a}$ \\
\hline $\begin{array}{l}\text { DH } 509 \mathrm{R}_{1} \\
\text { (red type) }\end{array}$ & After storage & $254.2 \mathrm{~d}$ & $110.8 \mathrm{~b}$ & $61.3 \mathrm{e}$ & $26.5 \mathrm{~b}$ \\
\hline \multirow{2}{*}{ 'Langedijker' } & After harvest & $273.2 \mathrm{de}$ & $248.8 \mathrm{~g}$ & $70.2 \mathrm{f}$ & $72.3 \mathrm{f}$ \\
\hline & After storage & $248.5 \mathrm{~d}$ & $193.6 \mathrm{ef}$ & $62.1 \mathrm{e}$ & $46.3 \mathrm{~d}$ \\
\hline \multirow{2}{*}{ 'Kissendrup' } & After harvest & $288.3 \mathrm{e}$ & $201.5 \mathrm{ef}$ & $74.3 \mathrm{f}$ & $60.0 \mathrm{e}$ \\
\hline & After storage & $213.2 \mathrm{c}$ & $210.8 \mathrm{f}$ & $50.1 \mathrm{c}$ & $51.2 \mathrm{~d}$ \\
\hline ‘Haco’ & After storage & $165.0 \mathrm{~b}$ & $146.1 \mathrm{~d}$ & $38.8 \mathrm{~b}$ & $34.4 \mathrm{bc}$ \\
\hline
\end{tabular}

*Values marked with the same letter within columns do not differ significantly at $p=0.05$ 
Table 1b. Content of individual phenolic groups in the analysed cabbage tissue (mg $\left.100 \mathrm{~g}^{-1} \mathrm{FW}\right)$

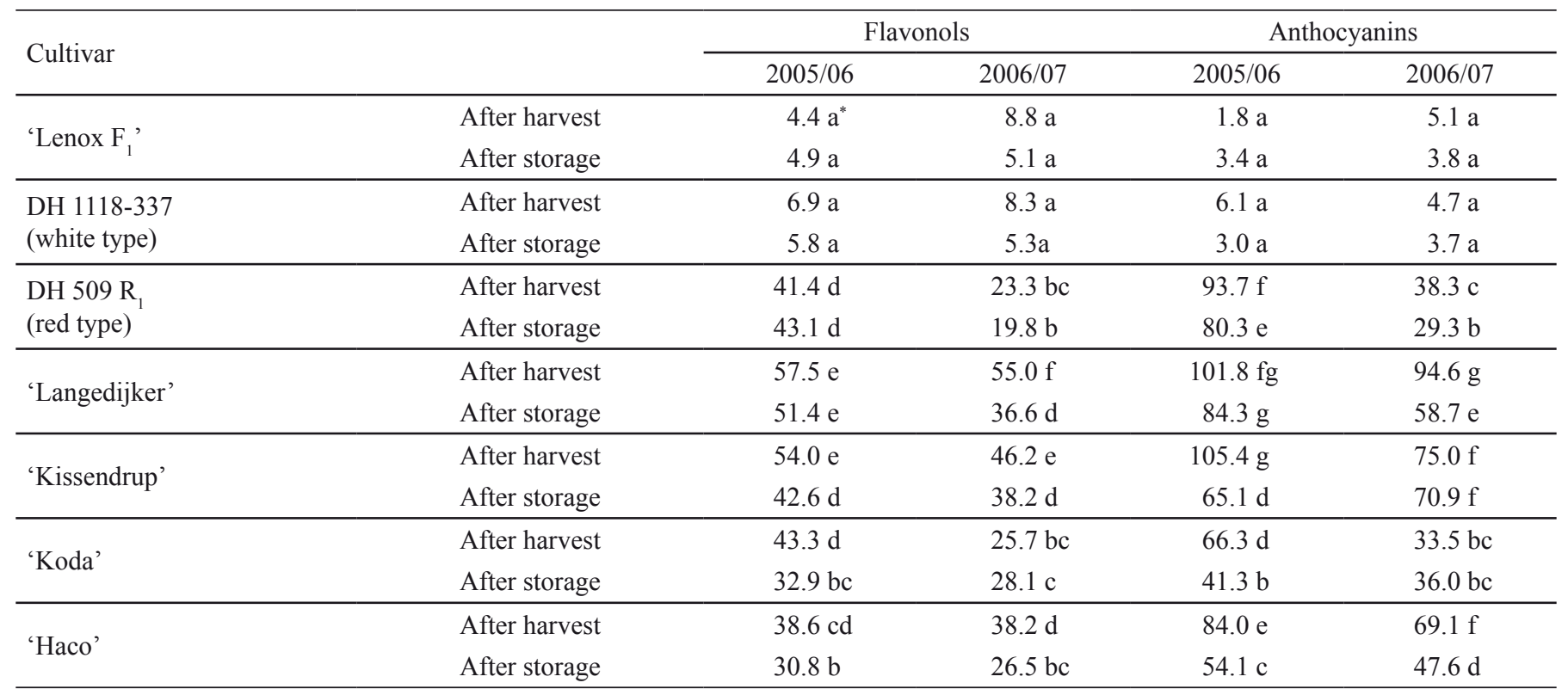

*Values marked with the same letter within columns do not differ significantly at $\mathrm{p}=0.05$

negligible (Tabs 1a and 1b). Total phenols were reduced significantly in the 'Kissendrup', 'Koda' and 'Haco' cultivars (2005/06) and in the 'Langedijker' and 'Haco' cultivars (2006/07). The levels of phenylpropanoids as well as that of flavonols were lower significantly after storage in the heads of most red cabbage cultivars. A decrease in anthocyanin content in the stored plants was especially distinct in 2005/06 ('Langedijker', 'Kissendrup', 'Haco') (Tab. 1b).

\section{Radical scavenging activity}

\section{DPPH method}

Radical scavenging activity detected by the method using $\mathrm{DPPH}^{*}$ in freshly harvested cabbage heads was considerably differentiated. This value of the white cabbage cultivar and the $\mathrm{DH}$ line of the white variety

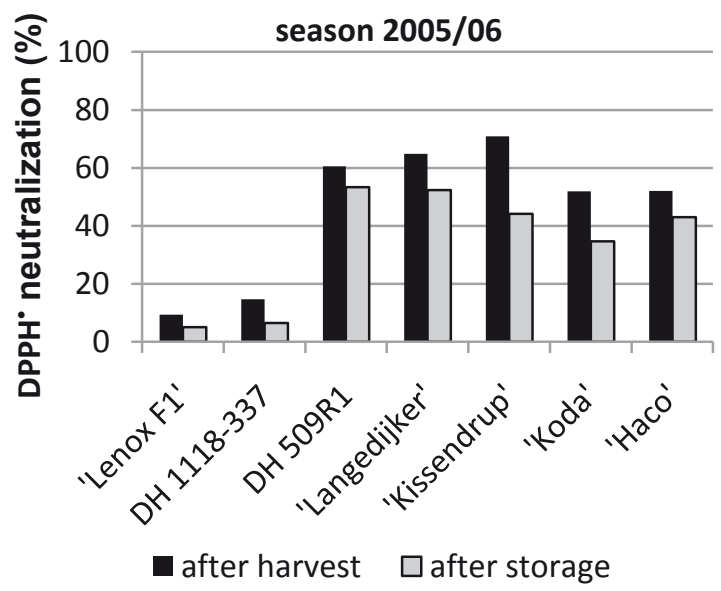

was very low in comparison with the high RSA (exceeding 50\%) observed in red cabbage samples. In the latter, a great variability was also shown (Fig. 1): in 2005 the lowest and the highest RSA were determined in 'Haco' (52\%) and in 'Kissendrup' (70.9\%), in the next year in DH 509 (26.6\%) and in 'Langedijker' (53.9\%), respectively.

During four-month storage in 2005/06, a significant decrease of radical scavenging activity in all examined cabbage cultivars was observed, while in 2006/07 either no significant changes or even a slight increase ('Kissendrup', 'Koda' and 'Haco') were noticed.

\section{$\underline{\text { ABTS method }}$}

In general, values of RSA determined by the ABTS method after harvesting were higher in comparison

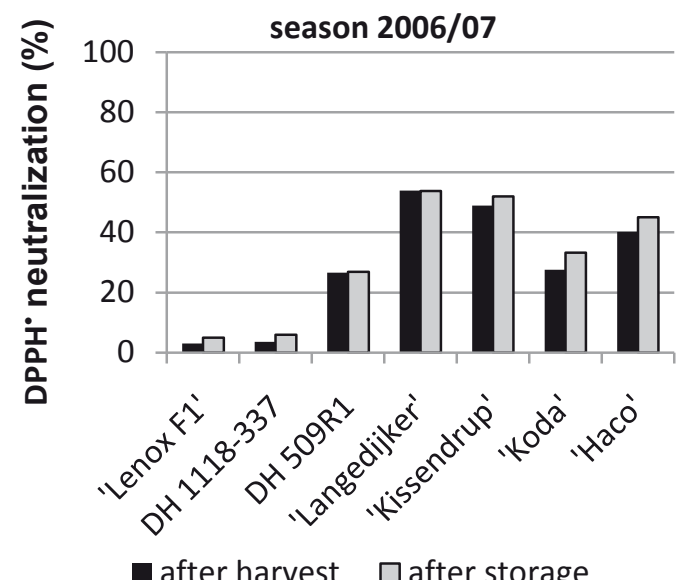

Figure 1. Radical scavenging activity (using $\mathrm{DPPH}^{\circ}$ ) of freshly harvested and stored cabbage in both vegetation seasons 

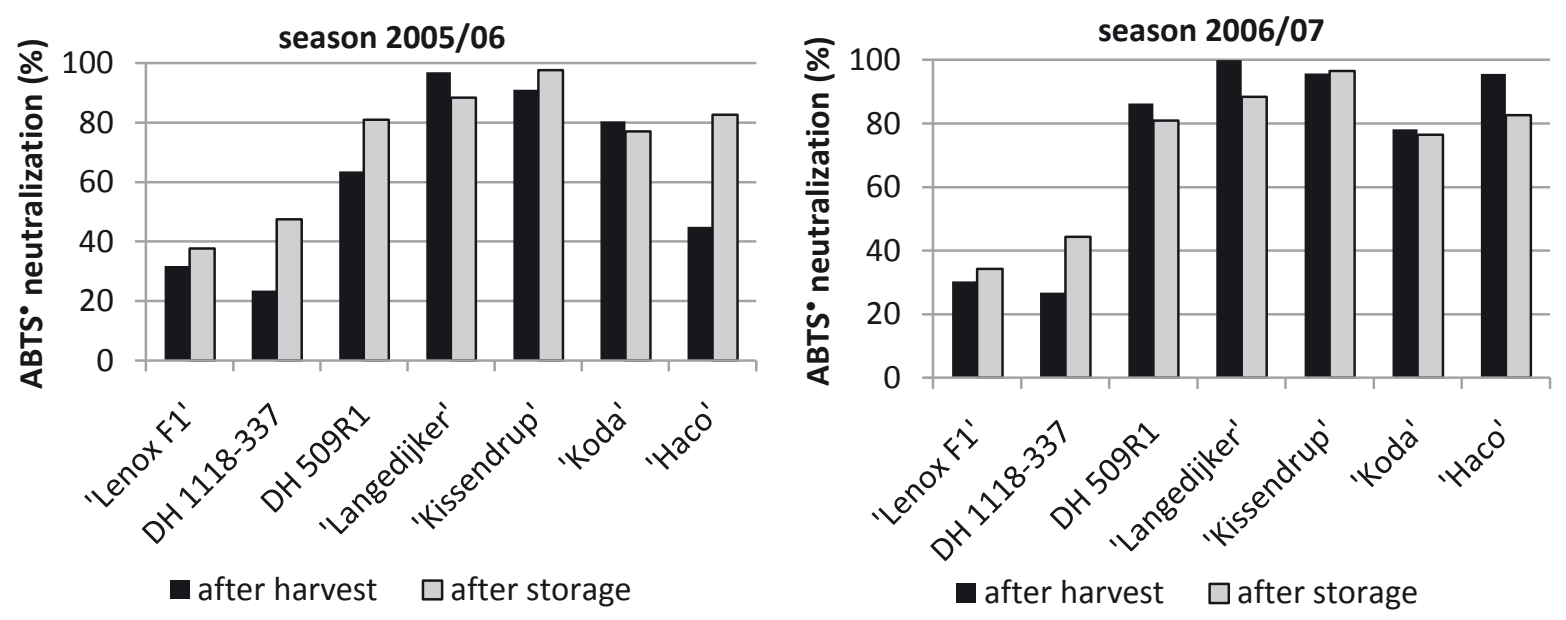

Figure 2. Radical scavenging activity (using ABTS•) of freshly harvested and stored cabbage in both vegetation seasons

with the DPPH method (Fig. 2). Similarly, as in the case of DPPH, the lowest RSA determined by ABTS ${ }^{\circ}$ was found in white cabbage, which, however, exceeded $30 \%$ ('Lennox $F_{1}$ ' in both years, DH 1118-337 in 2006/07). Antiradical activity in red cabbage was very high in both seasons of the experiment and reached the maximum for 'Langedijker' (97.0\% and $99.9 \%$ in 2005 and 2006 , respectively), while the lowest values were found in the case of 'Haco' in 2005 (45.0\%) and 'Koda' in 2006 (78.2\%).

Long-term storage did not result in distinct changes in RSA. In most cases, no statistically significant differences were observed, except the increase of RSA in both DH lines and in the 'Haco' cultivar (2005/06), as well as the decrease in 'Haco' and 'Langedijker' noted in 2006/07.

\section{DISCUSSION}

The level of phenolic substances (total, as well as those of individual groups) in the present experiment was much higher in red cabbage in comparison with the two white cabbage cultivars. Total phenol content determined in the latter (31-43 mg $100 \mathrm{~g}^{-1} \mathrm{FW}$ ) agreed with our previous investigations (Leja et al. 2006), where $25 \mathrm{DH}$ lines of white cabbage were examined and the total phenol content ranged between $43.1-66.0 \mathrm{mg} 100 \mathrm{~g}^{-1} \mathrm{FW}$. According to Singh et al. (2006), the level of total phenolics estimated in 14 cultivars of white cabbage was between 12.58 -34.41 mg $100 \mathrm{~g}^{-1} \mathrm{FW}$; similar content (15.3-36.7 mg 100 $\left.\mathrm{g}^{-1} \mathrm{FW}\right)$ of these compounds was noticed by Podsędek (2007). Among the phenolics present in white cabbage plants, quercetin and kempferol glycosides as well as hydroxycinamic acid esters predominated (Heimler et al. 2006).

In the case of red cabbage, a profound accumulation of phenolics was observed, reaching up to $288 \mathrm{mg} 100$ $\mathrm{g}^{-1} \mathrm{FW}$. In our previous study with red cabbage of the
'Langedijker' cultivar, total phenol content also exceeded $200 \mathrm{mg} 100 \mathrm{~g}^{-1}$ FW (Leja et al. 2005); however, Singh et al. (2006) reported lower level of these substances (101.3 mg $100 \mathrm{~g}^{-1} \mathrm{FW}$ ). A major phenolics characteristic for red cabbage are flavonoids, particularly anthocyanins (Walkowiak-Tomczak and Czapski 2007, Lin et al. 2008). In the present study the level of these constituents in red cabbage exceeded even $100 \mathrm{mg} 100 \mathrm{~g}^{-1}$, while it was very low in the white cabbage samples. According to recent data, the principal anthocyanins of red cabbage are cyanidin glycosides, acetylated with sinapic, ferulic, malonic and p-coumaric acids (Walkowiak-Tomczak and Czapski 2007). Lin et al. (2008) used the HPLC method to estimate malvidin glycosides in red cabbage. McDougall et al. (2007) found 18 different anthocyanin structures in extracts of fresh and preserved red cabbage. Similarly, as in a report by Walkowiak-Tomczak and Czapski, the predominant pigments were acetylated cyanidin glycosides and pelargonidin-3-glucoside (McDougall et al. 2007, Posmyk et al. 2009).

Antioxidant activity in Brassica species is correlated with vitamin $\mathrm{C}$ and total phenolic content (Hounsome et al. 2009). In the previous investigations (Laszczak et al. 2007), ascorbic acid content in red and white cabbage was not so distinctly differentiated as phenolic substances estimated in the present study, hence, high antiradical activity determined in red cabbage in comparison with the samples of two white cabbage cultivars was probably due to phenolics, especially those of the phenylpropanoids and anthocyanins groups. According to Rice-Evans et al. (1997), polyphenols possess the ideal chemical structure for free radical scavenging and seem to be more effective antioxidants than vitamins $\mathrm{E}$ and $\mathrm{C}$. In the case of phenolic acids, antiradical activity is positively correlated with the number of hydroxyl groups bonded to the aromatic ring (Sroka and Cisowski 2003). Among 
anthocyanins, those with o-dihydroxyl substitution (such as cyanidin, delphinidin and petunidin) are most susceptible to oxidation (Castañeda-Ovando et al. 2009).

In the present study, radical scavenging activity was measured by two methods: with DPPH and ABTS reagents. In the case of ABTS, antiradical activity was higher as related to the DPPH method. A similar effect, though less distinct, was described by Kusznierewicz et al. (2008) for RSA estimated in white cabbage assays. The various results obtained by these two chemical methods might have been due to the reaction of different phenolics with free radicals of different chemical structures.

Long-term cold storage caused decrease of phenolic substances in red cabbage heads, while the reaction of white cabbage cultivars was non-significant. The reduction of phenolics (total and those of individual groups) corresponded to a decrease in RSA only in 2005/06 and only when the DPPH method was applied. In general, changes in antiradical activity measured by the ABTS method were negligible. In our former studies with $25 \mathrm{DH}$ lines of stored white cabbage, a significant accumulation of total phenols was observed in most cases; however, in three lines a decrease was noticed (Leja et al. 2006). Four-month storage at $5^{\circ} \mathrm{C}$ of the heads of the red 'Langedijker' cultivar resulted in a considerable decrease in phenolic content of all groups, not accompanied by changes in radical scavenging activity (Leja et al. 2005). The controversial data can be explained by an interesting report concerning winter storage of white cabbage (Hounsome et al. 2009). The authors identified a broad spectrum of phenolics, such as 11 derivatives of phenolic acids and 15 flavonoids in freshly harvested plants. Their composition changed after a six-month storage period: six of the flavonoids were present during the entire storage period, while seven of them were lost after five months; some phenolic acids (mainly caffeic) disappeared after winter storage but two (phenylacetic and rosmarinic) appeared later. The variability described above in the composition of phenolic constituents affected by storage can be reflected in the differentiation both of their levels and antioxidative properties.

The qualitative and quantitative identification of individual phenolic substances in red cabbage tissue could elucidate more precisely their fluctuation as well as the variability in free radical neutralization.

\section{REFERENCES}

Can N.O., Altiokka G., 2007. Quantitative analysis of natural antioxidants pelargonidin and peonidin in fresh vegetables using an ODS-3 liquid chromatography column. Toxicol. Lett. 172S: S225.
Cano A., Alcaraz C., Arnao M.B., 2003. Free radicalscavenging activity of indolic compounds in aqueous and ethanolic media. Anal. Bioanal. Chem. 376: 33-37.

Castañeda-Ovando A., Pacheco-Hernández M.L., PáezHeRnÁNDEZ M.E., 2009. Chemical studies of anthocyanins: A review. Food Chem. 113: 859-871.

Fukumoto L.R., Mazza G., 2000. Assesing antioxidant and prooxidant activities of phenolic compounds. J. Agric. Food Chem. 48(8): 3597-3604.

Heimler D., Vignolini P., Dini M.G., Vincieri F.F., Romani A., 2006. Antiradical activity and polyphenol composition of local Brassicaceae edible varieties. Food Chem. 99: 464-469.

Hounsome N., Hounsome B., Tomos D., Edwards-Jones G., 2009. Changes in antioxidant compounds in white cabbage during winter storage. Postharv. Biol. Technol. 52(2): 173-179.

Kusznierewicz B., Bartoszek A., Wolska L., Drzewiecki J., Gorinstein S., NAMIEŚNiK J., 2008. Partial characterization of white cabbages (Brassica oleracea var. capitata f. alba) from different regions by glucosinolates, bioactive compounds, total antioxidant activities and proteins. LWT 41(1): 1-9.

Laszczak P., Szczeponek A., Wesolowska M., Leja M., 2007. Porównanie zawartości wybranych składników w główkach kapusty głowiastej czerwonej i białej. Nowaczyk P (ed.) Monography - Naturalna i indukowana zmienność W genetycznym doskonaleniu roślin ogrodniczych: 67-72.

Leja M., Mareczer A., Adamus A., Strzetelski P., Combik M., 2006. Some antioxidative properties of selected white cabbage DH lines. Folia Hort. 18(1): 31-40.

Leja M., Wyżgolik G., Kamińska I., 2007. Some parameters of antioxidant capacity of red cabbage as related to different forms of nutritive nitrogen. Folia Hort. 19(1): 15-23.

Leja M., Wyżgolik G., MareczeK A., 2005. Phenolic compounds of red cabbage as related to different forms of nutritive nitrogen. Hort. Veg. Grow. 24(3): 421-428.

Lin J.Y., Li C.Y., HwANG I.F., 2008. Characterization of the pigment components in red cabbage (Brassica oleracea L. var.) juice and their anti-inflammatory effects on LPSstimulated murine splenocytes. Food Chem. 209(4): 771-781.

McDougall G.J., Fyffe S., Dobson P., Stewart D., 2007. Anthocyanins from red cabbage - stability to simulated gastrointestinal digestion. Phytochem. 68: 1285-1294.

Pekkarinen S.S., Stöckmann H., Schwarz K., Heinonen I.M., Hopia A.I., 1999. Antioxidant activity and partitioning of phenolic acids in bulk and emulsified methyl linoleate. J. Agric. Food Chem. 47: 3036-3043.

PodsęDeK A., 2007. Natural antioxidants and antioxidant capacity of Brassica vegetables: A review. LWT 40: $1-11$.

Posmyk M.M., Kontek R., Janas K.M., 2009. Antioxidant enzymes activity and phenolic compounds content in red cabbage seedlings expose to copper stress. Ecotoxicol. Environ. Safety 72: 596-602. 
Proteggente A.R., Pannala A.S., Paganga G., van Buren L., Wagner E., Wiseman S., van de Put F., Dacombe C., RiceEvans C.A., 2002. The antioxidant activity of regularly consumed fruit and vegetables reflects their phenolic and vitamin C composition. Free Radical Res. 36(2): 217-233.

Rice-Evans C.A., Miller N.J., Paganga G., 1997. Antioxidant properties of phenolic compounds. Trends Plant Sci. 2(4): 152-159.

Singh J., Upadhyay A.K., Bahadur A., Singh B., Singh K.P., RAI M., 2006. Antioxidant phytochemicals in cabbage (Brassica oleracea L. var. capitata). Sci. Hort. 108(3): 233-237.

SRoKa Z., Cisowski W., 2003. Hydrogen peroxidase scavenging, antioxidant and anti-radical activity of some phenolic acids. Food Chem. Toxicol. 41(6): 753-758.

WaLkowiak-Tomczak D., CZAPSKi J., 2007. Colour changes of preparation from red cabbage during storage in a model system. Food Chem. 104: 709-714.

FENOLE, JAKO GLÓWNE ZWIĄZKI ANTYOKSYDACYJNE W KAPUŚCIE CZERWONEJ

Streszczenie: Oznaczono zawartość związków fenolowych (sumy fenoli, fenylopropanoidów, flawonoli i antocyjanów) oraz aktywność antyoksydacyjną w kapuście głowiastej czerwonej. Materiałem były cztery odmiany i dwie linie DH (jedna otrzymana z kapusty głowiastej białej, a druga z kapusty głowiastej czerwonej) oraz odmiana kapusty głowiastej białej 'Lennox $\mathrm{F}_{1}$ ' (zastosowana jako wzorzec).

Poziom fenoli oraz aktywność antyoksydacyjna były znacznie wyższe w tkance kapusty czerwonej niż białej. Obserwowano zróżnicowanie pomiędzy poszczególnymi obiektami kapusty czerwonej. W przypadku kapusty czerwonej po czteromiesięcznym przechowywaniu główek zaobserwowano istotny spadek zawartości związków fenolowych, czego nie odnotowano w kapuście białej.

Aktywność antyrodnikowa nie zmieniła się istotnie po przechowywaniu z wyjątkiem sezonu 2005/06, w którym nastąpił spadek aktywności (mierzonej przy użyciu $\mathrm{DPPH}^{*}$ ). Wartości aktywności antyrodnikowej oznaczane za pomocą metody ABTS były wyższe niż przy użyciu DPPH*.

Received September 23, 2009; accepted April 28, 2010 